\title{
Aspects regarding the propagation of Thuja occidentalis 'Columna' using different rooting substrates
}

\author{
Anna-Mária SZÁSZ-LEN ${ }^{1)}$, Liviu HOLONEC ${ }^{* *}$, Alina TRUȚA ${ }^{1)}$, Florin Alexandru REBREAN ${ }^{11}$ \\ ${ }^{1)}$ Department of Forestry, University of Agricultural Sciences and Veterinary Medicine Cluj-Napoca, \\ Mănăștur street 3-5, 400372, Cluj-Napoca; \\ ${ }^{*}$ corresponding author, e-mail: lholonec@yahoo.com
}

BulletinUASVM Horticulture 72(1) / 2015

Print ISSN 1843-5254, Electronic ISSN 1843-5394

DOI:10.15835/buasvmcn-hort:10998

\begin{abstract}
Ornamental trees planted inside the urban places: in gardens or in parks, around the buildings play an important role in ecology of human habitats. One of the most frecvently used ornamental conifer in Romania is Thuja occidentalis 'Columna', because it can be used in a wide variety of urban landscapes. This paper adresses the study of propagation of Thuja occidentalis 'Columna' using differente categories of rooting substrates. Choosing the ideal proportion and composition of rooting substrate is crucial in the propagation of Thuja occidentalis 'Columna'. Experiments were conducted at the „Mihai Viteazu” Nursery Garden from Turda, in spring 2013. The types and mixtures of rooting substrate used in the experimentwere: $100 \%$ peat (V1); $100 \%$ sand (V2); $50 \%$ peat $+50 \%$ perlite (V3); $50 \%$ peat $+50 \%$ sand (V4); $50 \%$ sand $+50 \%$ perlite (V5). Peat was used to improve the rooting substrate structure and to increase water retention. Sand drains quickly and retains minerals efficiently. Horticultural perlite has the ability to absorb water and then releasing it over a long time due to its porous structure. In order to obtain more meaningful results we planted 450 cuttings, 90 in each substrate type. Statistical analysis of the influence of rooting substrate on the number of roots per cuttings showed significantly positive differences in substrate V5. Final results indicated that V5 substrate is the best for production by cuttings of Thuja occidentalis 'Columna'. Compared to the mean of experiment considered control the best V5 rooting substrate provided 100\% rooting and 10.7 average numbers of roots per cuttings, with an average length $5.7 \mathrm{~cm}$ per cuttings after 18 weeks.
\end{abstract} length

Keywords: cuttings, Thuja occidentalis L. cv. 'Columna', rooting substrate, average root number, average root

\section{INTRODUCTION}

Ornamental trees planted inside the urban areas, such as gardens and parks, or around the buildings, play an important role in ecology of human habitats. One of the most frequently used ornamental conifer of Cupressaceae family in Romania is Thuja occidentalis L. cv. 'Columna', because it can be used in a wide variety of urban landscapes.

Thuja occidentalis L. cv.'Columna' is an ornamental cultivar of Thuja occidentalis specie, cataloged and described by Spaeth in 1904 and 1905 (Den Ouden and Boom, 1965). T. occidentalis L. cv.'Columna' can reach a height up to 4-5 m, the shoots and leaves are smaller than the variety 'Compacta pyramidalis' has. Compared to other columnar forms like 'Fastigiata' or ,Pyramidalis', 'Compacta' is the most recommended for vegetative propagation. Other traits of 'Columna' cultivar are identical with the traits of original species, it has a linear trunk, the bark has a brownreddish color and peel into strips, the shoots are compressed and has a dark green color on dorsal surface and pale green color on ventral surface. The scale-like leaves encompass the shoots, the flowers are unisexual and monoecious, the cones are small, 1-1.5 cm long, narrow and ovoid with overlapping scales. The small and flat seeds has 
wings on both side, two seeds are situated on the armpit of a scale (Stănescu, 1979; Schmidt and Tóth, 2006).

Generative reproduction through seeds does not ensure faithful transmission of ornamental traits always (Ragonezi et al., 2010), some varieties and forms of Thuja occidentalis (Fastigiata, Piramidalis, Globosa) fructify rarely, others tend to escape through generative reproduction (Negruțiu, 1980). Vegetative propagation by cuttings, remove all these shortcomings and is far the cheapest solution to produce ornamental seedlings (Ragonezi et al., 2010).

This paper addresses the study of propagation of Thuja occidenatalis L. cv. 'Columna' using different rooting substrates. Choosing the ideal proportion and composition of rooting substrate is crucial in the propagation of Thuja occidenatalis L. cv. 'Columna'. Some studies addressed the propagation of Thuja occidentalis and varieties (Florincescu et al., 1997; Griffin et al., 1998; Davidescu et al., 2003; Stan, 2008; Vlad et al., 2008a; Iglesias Díaz et al., 2009; Ciubotaru and Roscha, 2011), but little has been reported on propagation of ,Columna' cultivar.

\section{MATERIALS AND METHODS}

Experiments were conducted at"Mihai Viteazul" Nursery Garden in Production Unit VIII belonging to Turda Forestry Department. The experiment was set in a modern Rovero greenhouse on $480 \mathrm{~m}^{2}$, with double polyethylene coating and with a $75 \mathrm{~kW}$ heating system. The „Mihai Viteazul” Nursery Garden annually producing about 70 000 rooted cuttings. The experiment started at 30 January 2013 and finished at 4 June 2013 taking126 days (18 week). Due to market demands, columnar forms are the most popular, and for this reason we started to study the 'Columna' variety of the Thuja occidentalis. Nowaday Thuja occidentalis 'Columna' is quite common and widespread in Transylvania. Cuttings were taken from young parent plants in the field of nursery in winter dormant period (Fig. 1).

To study the effect of rooting substrate on rooting capacity of cuttings we used five experimental rooting substrate (Tab. 1). Cuttings were planted in $10-11 \mathrm{~cm}$ height edaphic layer in boxes with $56.5 \times 36.5 \mathrm{~cm}$ size.

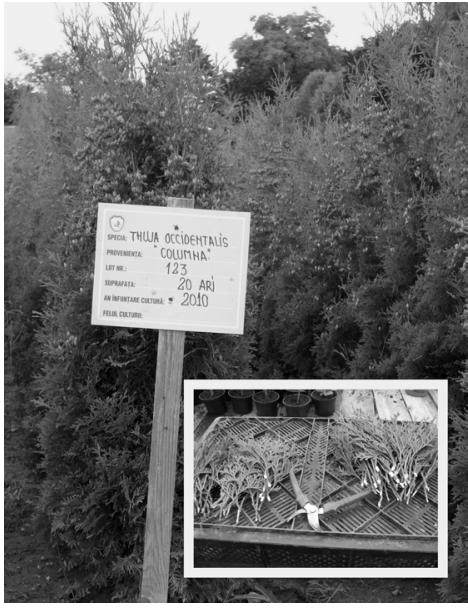

Fig. 1. Young parent plants of Thuja occidentalis ,Columna'

Tab. 1. Composition of rooting substrate

\begin{tabular}{lc}
\hline Rooting substrate & Composition \\
\hline Variant 1 (V1) & $100 \%$ peat \\
\hline Variant 2 (V2) & $100 \%$ sand \\
\hline Variant 3 (V3) & $50 \%$ peat $+50 \%$ perlite \\
\hline Variant 4 (V4) & $50 \%$ peat $+50 \%$ sand \\
\hline Variant 5 (V5) & $50 \%$ sand $+50 \%$ perlite \\
\hline
\end{tabular}

Peat is used in vegetative propagation to improve the substrate structure and to increase water retention. Sand drains quickly and retains minerals efficiently. Horticultural perlite due to its porous structure has the ability to absorb water and then releasing it over a long time (Cole et al., 2002). In order to obtain more conclusive results it was planted 450 cuttings, 90 cuttings in the above described five rooting substrate with 4-4.5 cm distance between rows and $3.5 \mathrm{~cm}$ distance between cuttings. During the rooting period, air temperature varied between 16-22 ${ }^{\circ} \mathrm{C}$ and substrate temperature varied between $18-20^{\circ} \mathrm{C}$, and the humidity varied between 75 $90 \%$ in the air and $65-75 \%$ in the substrate. Light was directed by shading above the cuttings. For the rooting of cuttings has not been used any rooting stimulants or soil fertilizer. The rooting process was monitored in the $12^{\text {th }}$ and $18^{\text {th }}$ week and results were noted in the field book. It was noted the number of rooted cuttings, the cuttings without roots and the number of roots and their size. The measurements were carried out with the graduated scale and with callipers, the accuracy is 
about $1 \mathrm{~mm}$. Data were processed as mean values, calculating the variability of mean root length and mean root number. Statistical analysis of variation one-way ANOVA was performed, the mean of the experiment was considered as control.

\section{RESULTS AND DISCUSSION Rooting percentage}

The total number of rooted cuttings varied from one substrate to another. Rooting percentage was 0 in the $\mathrm{V} 4$ substrate. Low rooting percentage $(42.22 \%)$ of Thuja occindentalis "Columna" cuttings was obtained in V1 and V3 substrates. The rooting percentage of the cuttings in substrate V2 reached 92.22\%, in V5 reached 100\% (Fig. 2).

The highest rooting percentage in the experiment was found in rooting substrate made of $50 \%$ sand $+50 \%$ perlite (V5) and in $100 \%$ sand (V2). In a previous study Thuja occidentalis cuttings had $90 \%$ rooting percentage in the substrate made from sand, and $93,3 \%$ in the perlite substrate (Stan, 2008). Ciubotaru and Roscha (2011) compared the effects of different rooting substrates $(100 \%$ perlite, $50 \%$ peat $+50 \%$ perlite, $100 \%$ sphagnum) with vegetative propagation of the cultivar Thuja occidentalis 'Danica'. The highest rooting percentage was found in the case of $100 \%$ perlite rooting substrate. Vlad et al. (2008a) found that Thuja occidentalis 'Danica' cuttings had a $89.3 \%$ rooting rate in a rooting substrate made of $50 \%$ peat coal $+50 \%$ perlite, while in $100 \%$ sand substrate had a $58.6 \%$ rooting rate. Thuja occidentalis ,Smaragd' cuttings with K-IBA $0.6 \%$ in talc powder reached $100 \%$ rooting percentage in substrate peat:perlite (2:1) under low polytunnels greenhouse without misting (Bielenin et al., 2003). The untreated Thuja occidentalis ,Fastigiata' cuttings has $82,7 \%$ rooting percentage in the sand substrate, and $70.7 \%$ rooting percentage in the perlite rooting substrate (Florincescu et al., 1997). Davidescu et al. (2003) found that propagation by cuttings of Thuja occidentalis L. 'Columna' and Thuja occidentalis 'Danica' was best in peat substrate. The rooting success of the Thuja plicata 'Atrovirens' cuttings ranged from $75 \%$ to $90 \%$ in substrates made of composts (100\% compost) or in mixes with coarse sand and pine bark compost (Iglesias-Díaz et al., 2008).

In the experiment carried out by Nouaim et al. (2002) with argan tree (Argania spinosa) softwood cuttings, Terragreen substrates gave the highest level of rooting (33\%), whereas it was low on vermiculite $(17 \%)$ and zero on 'Oil dri' siliceous substrate. According to a study conducted by Ngo Mpeck (2009) sand substratate and 50:50 mixture of sand and sawdust had significant effects on the rooting percentage of African whitewood (Annickia chlorantha) leafy stem cuttings.

\section{INFLUENCE OF ROOTING SUBSTRATE ON AVERAGE ROOT NUMBER OF THUJA OCCIDENTALIS, COLUMNA' CUTTINGS}

Rooting quality could be given by the average root number per cutting. In substrate V5 the average number of roots per cuttings had the highest values both in the $12^{\text {th }}(5,3$ average root number) and $18^{\text {th }}(10,7$ average root number $)$ week. Cuttings in V2 substrate had many roots

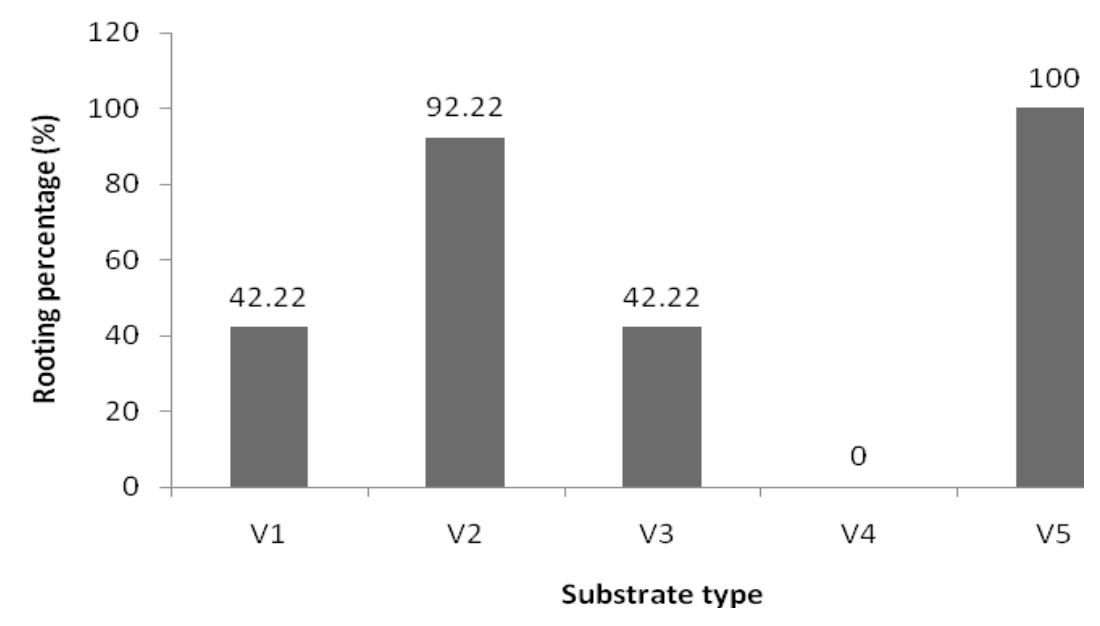

Fig. 2. Rooting percentage of Thuja occidentalis 'Columna' cuttings in the rooting substrates 
also. The rooting process of cuttings in $\mathrm{V} 1$ and V3 substrates after a good start in the $12^{\text {th }}$ week, stopped to the $18^{\text {th }}$ week (Tab. 2).

Statistical analysis of the influence of rooting substrate on the number of roots per cuttings shows significant differences in V5 substrate. The influence of seedbed on rooted cuttings in V4 substrate show a significantly distinctly low difference (Tab. 2).

The average root number per cutting had different values for each studied rooting substrate in the $12^{\text {th }}$ week, resulting an average root number per cutting between 2 (V3 substrate) and 5.3 (V5 substrate). Compared with the experience average (2.6) considered control, the average root number in rooting substrates V1, V2 and V5 showed higher mean root numbers $3,5.3$, respectively 2.7. The coefficient of variability calculated for the average root number per cuttings had superior values except V4 substrate. The mean $\mathrm{CV} \%$ in the experience was $31.6 \%$ and the extreme limits of $\mathrm{CV} \%$ for the average root number ranged between $0 \%$ (V4) and $57.7 \%$ (V1).

The average root number per cuttings in the $18^{\text {th }}$ week was different in each studied rooting substrate, resulting a variation between 4.3 (V3 substrate) and 10.7 (V5 substrate). Compared with the experience average (5.6) considered control, the average root number in rooting substrate V2 and V5, showed higher values 8 and 10.7. The coefficient of variability calculated for the average root number per cutting showed high values except V4 substrate. Mean CV\% on experience was $18.52 \%$ and the extreme limits of CV\% for the average root number ranged between $0 \%$ (V4 substrate) and $40 \%$ (V1 substrate).

Tab. 2. Influence of rooting substrate on average root number of Thuja occidentalis ,Columna' cuttings

\begin{tabular}{|c|c|c|c|c|c|c|c|c|}
\hline \multirow[t]{2}{*}{ Substrate type } & \multicolumn{2}{|c|}{$\begin{array}{c}\text { Average root number in } \\
\text { the } 12^{\text {th }} \text { week }\end{array}$} & \multirow{2}{*}{$\begin{array}{l}\text { Signifi- } \\
\text { cation }\end{array}$} & \multirow[t]{2}{*}{$\mathrm{CV} \%$} & \multicolumn{2}{|c|}{$\begin{array}{c}\text { Average root number in } \\
\text { the } 18^{\text {th }} \text { week }\end{array}$} & \multirow{2}{*}{$\begin{array}{l}\text { Signifi- } \\
\text { cation }\end{array}$} & \multirow[t]{2}{*}{$\mathrm{CV} \%$} \\
\hline & Absolute & Relative & & & Absolute & Relative & & \\
\hline V1 & 3.0 & 115.4 & - & 57.7 & 5.0 & 89.3 & - & 40.0 \\
\hline $\mathrm{V} 2$ & 2.7 & 102.6 & - & 21.7 & 8.0 & 142.9 & - & 25.0 \\
\hline V3 & 2.0 & 76.9 & - & 50.0 & 4.3 & 77.4 & - & 13.3 \\
\hline V4 & 0.0 & 0.0 & o & 0.0 & 0.0 & 0.0 & 00 & 0.0 \\
\hline V5 & 5.3 & 205.1 & $*$ & 28.6 & 10.7 & 190.5 & $* *$ & 14.3 \\
\hline \multirow[t]{4}{*}{ Exp. average (Mt.) } & 2.6 & 100.0 & - & 31.6 & 5.6 & 100.0 & - & 18.52 \\
\hline & DL 5\% & 2.3 & & & DL 5\% & 2.9 & & \\
\hline & DL 1\% & 3.3 & & & DL 1\% & 4.2 & & \\
\hline & DL $0.1 \%$ & 5 & & & DL $0.1 \%$ & 6.3 & & \\
\hline
\end{tabular}

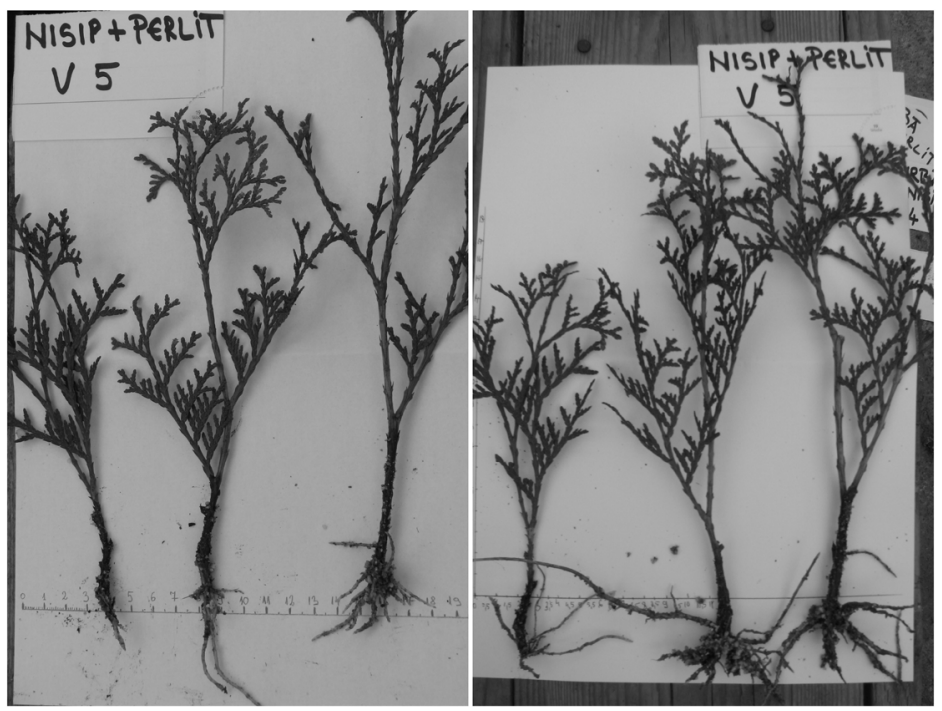

Fig. 3. Thuja occidentalis ,Columna' cuttings in substrate V5 in the $12^{\text {th }}$ and $18^{\text {th }}$ week of rooting period. 
Rooting substrate composed of $50 \%$ sand + $50 \%$ perlite (V5) positively influenced the number of roots formed per Thuja occidentalis 'Columna' cuttings (Fig. 3). In a previous study Ciubotaru and Roscha (2011) observed that the average root number per Thuja occidentalis ,Danica' cuttings was positively influenced by rooting substrate made of $50 \%$ peat $+50 \%$ perlite.

Griffin et al. (1998) found that mean root number per cutting was 6 in the $6^{\text {th }}$ week of vegetative propagation of semi-hardwood Thuja $\mathrm{L}$. $\mathrm{x}$,Green Giant' cuttings (hybrid of Thuja plicata J. Donn ex D. Don x Thuja standishii (Gord.) Carriere). The average root number of untreated Thuja occidentalis 'Danica' cuttings planted in January was 6.19 in $100 \%$ perlite substrate, 7.6 in peat and perlite (1:1) substrate and 8.18 in 100\% Sphagnum rooting substrate (Ciubotaru and Roscha, 2011). Vlad et al. (2008b) found that mean number of roots per Thuja orientalis ,Aurea' cuttings varied in the different rooting substrates: 7.2 in 100\% perlite substrate, 9.2 in $100 \%$ peat substrate and 11.8 in $50 \%$ peat $+50 \%$ perlite substrate after 150 days of rooting period.

\section{INFLUENCE OF ROOTING SUBSTRATE ON AVERAGE ROOT LENGTH OF THUJA OCCIDENTALIS, COLUMNA' CUTTINGS}

The enhanced rooting capacity of cuttings mark out also from the length of roots of newly formed plantlets. The root length varies according to developing period and depend on the rooting substrate. The evolution of rooting process of
Thuja occidentalis "Columna" cuttings shows that those cuttings which had the longest roots in the $12^{\text {th }}$ week were not necessarily have in the $18^{\text {th }}$ week. In the $12^{\text {th }}$ week cuttings of V1 and V3 substrate had the longest average root length, 3 $\mathrm{cm}$ and $2.7 \mathrm{~cm}$. In the $18^{\text {th }}$ week cuttings in V3 and V5 had the longest average root length, $7.6 \mathrm{~cm}$ and $5.7 \mathrm{~cm}$ (Tab. 3).

After analyzing the influence of rooting substrate on the root length of Thuja occidentalis 'Columna' cuttings, no significant difference was shown to the mean of experiment (Control). Toward rooting substrate V4 was found as significantly distinct lower difference. Based on the calculated coefficient of variability it can be stated that the root length variability is large, except V4 substrate (Tab. 3).

Mean CV\% in the $12^{\text {th }}$ week was $30.46 \%$ and the extreme limits of CV\% for average root length ranged between $0 \%$ (V4 substrate) and $47.2 \%$ (V3 substrate). In the $18^{\text {th }}$ week the average value of CV\% was $23.86 \%$ and the extreme limits of CV\% for average root length ranged between $0 \%$ (V4 substrate) and $43.3 \%$ (V2 substrate).

It was observed that in the case of Thuja occidentalis 'Columna' the four rooting substrate (V1, V2, V3, V5) did not influenced the root length per cutting. In contrast we found that V4 rooting substrate influenced negatively the root length.

In the experiment the average root length per Thuja occidentalis ,Columna' cutting did not show any significant differences between rooting substrates. According to Florincescu

Tab. 3. Influence of rooting substrate on average root length of Thuja occidentalis ,Columna' cuttings

\begin{tabular}{|c|c|c|c|c|c|c|c|c|}
\hline \multirow[t]{2}{*}{ Substrate type } & \multicolumn{2}{|c|}{$\begin{array}{l}\text { Average root length } \\
\text { in the } 12^{\text {th }} \text { week }(\mathrm{cm})\end{array}$} & \multirow{2}{*}{$\begin{array}{l}\text { Signifi- } \\
\text { cation }\end{array}$} & \multirow[t]{2}{*}{ CV\% } & \multicolumn{2}{|c|}{$\begin{array}{l}\text { Average root length } \\
\text { in the } 18^{\text {th }} \text { week }(\mathrm{cm})\end{array}$} & \multirow{2}{*}{$\begin{array}{l}\text { Signifi- } \\
\text { cation }\end{array}$} & \multirow[t]{2}{*}{$\mathrm{CV} \%$} \\
\hline & Absolute & Relative & & & Absolute & Relative & & \\
\hline V1 & 3.0 & 167.9 & - & 33.3 & 4.5 & 103.5 & - & 11.1 \\
\hline $\mathrm{V} 2$ & 1.5 & 84.0 & - & 33.3 & 4.0 & 92.0 & - & 43.3 \\
\hline V3 & 2.7 & 149.3 & - & 47.2 & 7.6 & 174.1 & - & 37.9 \\
\hline V4 & 0.0 & 0.0 & 0 & 0.0 & 0.0 & 0.0 & o & 0.0 \\
\hline V5 & 1.8 & 98.9 & - & 38.5 & 5.7 & 130.4 & - & 27 \\
\hline \multirow[t]{4}{*}{ Exp. average (Mt.) } & 1.8 & 100.0 & - & 30.46 & 4.3 & 100.0 & - & 23.86 \\
\hline & DL 5\% & 1.7 & & & DL 5\% & 3.5 & & \\
\hline & DL 1\% & 2.4 & & & DL 1\% & 5.1 & & \\
\hline & DL $0.1 \%$ & 3.6 & & & DL0.1\% & 7.6 & & \\
\hline
\end{tabular}


et al. (1997) the untreated Thuja occidentalis ,Fastigiata' cuttings had $9.76 \mathrm{~cm}$ average root length in sand substrate and $21.31 \mathrm{~cm}$ average root length in perlite substate after 130 days from the planting. Chen et al. (2003) found that the total root length per cutting of Dwarf Umbrella Tree (Schefflera arboricola) after 21 days of sticking was significantly affected by rooting substrates. According to the results of Danehloueipour et al. (2006), chickpea (Cicer arietinum L.) cuttings in sand and potting mix substrate produced higher rooting rate $(79.4 \%)$ and root length $(2.9 \mathrm{~cm})$.

\section{CONCLUSION}

In the vegetative production of Thuja occidentalis 'Columna' it is recommended to use $50 \%$ sand and $50 \%$ perlite rooting substrate (V5). This will bring to obtain in a relatively short period of time many viable and healthy seedlings.

Final results indicate that $V 5$ rooting substrate is the best in the production by cuttings of Thuja occidentalis 'Columna'. Compared to the mean of experiment considered control the best $\mathrm{V} 5$ rooting substrate provided $100 \%$ rooting and 10.7 average numbers of roots per cuttings, with an average length $5.7 \mathrm{~cm}$ per cuttings after 18 weeks.

\section{REFERENCES}

1. Bielenin M (2003). Rooting and gas exchange of conifer cuttings treated with indolebutyric acid. Journal of Fruit and Ornamental Plant Research 11:99-105.

2. Chen J, McConnell DB, Robinson CA, Caldwell RD, Huang Y (2003). Rooting Foliage Plant Cuttings in Compost formulated Substrates. HortTechnology 13(1):110-114.

3. Ciubotaru A, Roshca I (2011). Vegetative propagation from cuttings of the cultivar Thuja occidentalis 'Danica' in plant trays. Rev. Bot., Vol.III, Nr.3, 115-121.

4. Cole JC, Dunn DE (2002). Expanded Polystyrene as a Substitute for Perlite in Rooting Substrate. J. Environ. Hort. 20(1):7-10.

5. Danehloueipour N, Yan G, Clarke HJ, Siddique KHM (2006). Successful stem cutting propagation of chickpea, its wild relatives and their interspecific hybrids. Australian Journal of Experimental Agriculture, 46:1349-1354.

6. Davidescu VE, Caretu G, Madjar RM, Stanica F, Peticila AG, Dumitrascu M (2003). The influence of substrate and cutting period on the propagation of some ornamental species. Acta Hort. (ISHS) 608:273-277

7. Den Ouden P, Boom BK (1965). Manual of cultivated conifers: hardy in the cold - and warm - temperature zone. Editura Academică Kluwer, pagina 417

8. Florincescu A, Pui A, Nicoară A (1997). Cutting propagation in Thuja occidentalis ,Fastigiata' using rooting stimulators. Not. Bot. Hort. Agrobot. Cluj, XXVI-XXVII:57-63

9. Griffin JJ, Blazich FA, Ranney TG (1998). Propagation of Thuja x 'Green Giant' by Stem Cuttings: Effects of Growth Stage, Type of Cutting, and IBA Treatment. J. Environ. Hort. 16(4):212-214.

10. Negruțiu F (1980). Spații verzi, Editura didactică și pedagogică. București.

11. Ngo Mpeck ML, Atangana AR, Omgba AM (2009). Temporal variation in rooting of Annickia chlorantha leafy stem cuttings. New Forests 38:273-283.

12. Nouaim R, Mangin G, Breuil MC, Chaussod R (2002). The argan tree (Argania spinosa) in Morocco: Propagation by seeds, cuttings and in-vitro techniques. Agroforestry Systems 54:71-81.

13. Ragonezi C, Klimaszewska K, Rui Castro M, Lima M, de Oliveira P, Zavattieri MA (2010). Adventitious rooting of conifers: influence of physical and chemical factors. Trees 24:975-992.

14. Schmidt G, Tóth I (2006). Kertészeti dendrológia [Horticultural Dendrology] Budapest, Mezőgazda Press, p. 414

15. Stan I (2008). The influence of the rooting substrate at 5 Gymnosperm species. Bulletin UASVM, Agriculture 65(1):264-267

16. Stănescu V (1979). Dendrologie. Editura Didactică și Pedagogică, București

17. Vlad M, Vlad I, Mester DG (2008a). The influence of the substrate on striking roots at the cuttings of Thuja occidentalis Danica. Bulletin UASVM, Horticulture 65(1): 494

18. Vlad M, Vlad I, Meșter I, Meșter D, Smit I (2008b). The influence of the subsoil layer on the rooting of Thuja orientalis "Aurea" plants. Analele Universității din Oradea, Fascicula: Protecția Mediului, XIII:234-236. 